\title{
Artificial reproduction and larval rearing of captive endangered Atlantic sturgeon Acipenser sturio
}

\author{
Patrick Williot $^{1,2, *}$, Thierry Rouault ${ }^{1}$, Marcel Pelard ${ }^{1}$, Daniel Mercier ${ }^{1}$, Louis Jacobs ${ }^{1}$ \\ ${ }^{1}$ Cemagref, Research Unit Estuarine Ecosystems and Diadromous Fish, 50 avenue de Verdun, 33612, Cestas Cedex, France
}

${ }^{2}$ Present address: 4 rue du Pas de Madame, 33980, Audenge, France

\begin{abstract}
In the early 1990s a functional ex situ brood stock of the European Atlantic sturgeon Acipenser sturio was initiated in France as the only means of saving the species from extinction. In late spring 2007, partial and complete oogenesis and complete spermatogenesis were recorded in fish which were born in the wild in 1994 and entered the hatchery in 1995. Here, we report on the 2007 artificial reproduction attempts, which represent a breakthrough in terms of conservation of $A$. sturio, and possibly some other sturgeon species. From their arrival in the hatchery, fish were held in brackish water $(\sim 15 \%)$. Pre-selected mature fish were transferred to fresh water for 5 wk prior to reproduction attempts. Morpho-physiological observations on testes and ovarian follicles (ovf) determined which fish were the ripest prior to hormonal injection. Three females were tested for in vitro maturation competence (IVMC) by recording the germinal vesicle breakdown (GVBD) in ovf. One of the fish that entered the hatchery in 1995 ovulated; the ovaries were fully developed and exhibited a decisive IVMC $(90 \%$ GVBD with added hormone and $0 \%$ GVBD in control). Two of the 5 hormonally stimulated males provided semen, both of which yielded similar embryological development results. Fertilization rates were $70-80 \%$, declining to $38-39 \%$ of survival at the onset of hatching. Eleven thousand larvae were obtained; these exhibited first feeding at 10 to $11 \mathrm{~d}$ post hatch at $18.4^{\circ} \mathrm{C}$. Although preliminary, these findings show promise for captive breeding of European Atlantic sturgeon.
\end{abstract}

KEY WORDS: Acipenser sturio - Captive specimen - Maturation of ovarian follicles · Artificial reproduction $\cdot$ Embryogenesis $\cdot$ Hatching

\section{INTRODUCTION}

The European Atlantic sturgeon Acipenser sturio (Linnaeus 1758) is an anadromous species which formerly inhabited all coastal western European countries and their main river drainages (Magnin 1962, Holcik et al. 1989). In the course of the 20th century the species disappeared from all these countries except France (see Williot et al. 2002a for a recent synthesis), where a very small population is still present, although spawning events are rare. As a result, the species is severely threatened and may be considered on the verge of extinction although it has had protected status in France since 1982 (Trouvery et al. 1984, Rochard et al. 1990). The species is classified as Critically Endangered by the International Union for Conversation of Nature
(IUCN). A restoration plan developed in the late 1970s included restocking measures (Williot et al. 1997). However, due to the dramatic decrease in the number of wild-originated brood fish and their poor reproductive status (Williot et al. 2002b), only 4 artificial reproduction events were attempted between 1981 and 2006: 1 in 1981, 2 in 1985 and 1 in 1995 (Williot et al. $2002 b, 2007)$. Of these attempts, only one (1995) successfully yielded larvae that were released (Williot et al. 2005a). The creation of a captive brood stock began in the early 1990s as a precautionary measure (Williot et al. 1997), as this was regarded as the last chance to prevent the sturgeon species from facing total extinction (Beamesderfer \& Farr 1997). Adult and juvenile fish of wild origin and artificially-produced fingerlings (from 1995) have constituted the captive brood stock in 
France. The species spends most of its life span in coastal ocean waters (Magnin 1962, Rochard et al. 1997). As juveniles caught in estuarine habitats are better acclimated to brackish water than freshwater (Williot et al. 2007), broodstock are now held in brackish water $(\sim 15 \%)$. In the captive brood stock from the mid-1990s, ripe males were frequently obtained, but only partial oogenesis was observed among the female fish, including the oldest ones (Williot et al. 2007).

The present study reports on the 2007 artificial reproduction of captive Acipenser sturio, which represents a breakthrough as regards the long-term success of ex situ conservation and restoration of the species. Moreover, these findings may be relevant to conservation initiatives for other endangered acipenserids.

\section{MATERIALS AND METHODS}

Fish. Initially, in May 2007, there were 79 fish divided into 3 groups to enable detailed observation and to attempt ex situ reproduction. Fish of Group 1 ( $n=8$ ) were the oldest fish and were of wild origin. They were born around 1988, ranged from 12 to $38 \mathrm{~kg}$, and were mature when they arrived at the hatchery, with the exception of the only female within this group. Group 2 consisted of 33 ind. born in the wild in 1994, the majority of which (24) were captured between March and December 1995 in the Gironde estuary (Williot et al. 2007). In spring 2007, they ranged from 4.5 to $27.8 \mathrm{~kg}$ and are believed to be full siblings (Ludwig et al. 2004). Fish of Group 3 were the progeny (full siblings) of the artificial reproduction performed in 1995 (Williot et al. 2000a) and these fish ranged from 6 to $16.2 \mathrm{~kg}$. With the exception of the fish in Group 1, the sex ratio was balanced. The fish were passive integrated transponder (PIT)-tagged, and a Petersen disc was fixed at the base of the dorsal fin to which coloured markers were also attached for easy identification of the fish within the tanks.

Rearing conditions. The fish were held in circular fibreglass tanks $(4 \times 1 \mathrm{~m}$ or $4 \times 2 \mathrm{~m}, \varnothing \times$ height, $h)$ installed in an isolated building. Each tank was part of a re-circulating system composed of a pump equipped with a basket to collect wasted food, a mechanical filter (effective surface of the filter, $S=0.63 \mathrm{~m}^{2} ; h=0.9 \mathrm{~m}$, filled with $500 \mathrm{~kg}$ of sand [0.8 to $1.2 \mathrm{~mm}])$, a biological filter $(\varnothing=$ $0.76 \mathrm{~m}, h=2 \mathrm{~m}$ filled with $1300 \mathrm{l}$ of Biogrog ${ }^{\mathrm{TM}}$ ), UV treatment apparatus, and a column $(\varnothing=0.2 \mathrm{~m}, h=1.3 \mathrm{~m}$ filled with 'Levapack' modules with a specific surface of $144 \mathrm{~m}^{2} \mathrm{~m}^{-3}$ ) for oxygen enrichment. Flow rate was maintained at 3.5 to $4.5 \mathrm{~m}^{3} \mathrm{~h}^{-1}$. Daily renewal included equal volumes (300 to 500 l) of fresh and seawater. Brackish water (14 to $16 \%$ ) was obtained by mixing freshwater and seawater in appropriate proportions. To protect against accidental escape, a $0.6 \mathrm{~m}$ high vertical wire fence was installed around the top of the tanks. The tanks were located in an isolated building supplied with a natural photoperiod provided by fairly low intensity lamps (50 and 100 lux) fixed over the centre of the 1 and $2 \mathrm{~m}$ deep tanks, respectively. The fresh water was bacteria-free well water supplied at a constant temperature of 17 to $18^{\circ} \mathrm{C}$, which was de-gassed and further oxygenenriched via a tower. Seawater was delivered by trucks and stored in large tanks with constant circulation, aeration, and UV sterilisation. Because Acipenser sturio is a benthic feeder, holding densities ranged from 1 to 1.5 ind. $\mathrm{m}^{-2}$ (i.e. 6 to $9 \mathrm{~kg} \mathrm{~m}^{-2}$ ).

Tank management. The only available food item that was accepted by fish on a fairly regular basis (over the long term) was shrimp. The fish were fed frozen shrimp (Palaemons longirostris or Crangon crangon) twice a day ad libitum, judged by the amount of uneaten food recovered every day from the tanks and the pump baskets. Fish were starved when transferred to freshwater. Uneaten feed was weighed in order to adapt the daily food ration, which was reduced when waste feed was $>15 \%$ of that offered. Overall, the daily shrimp portion ranged between 1.2 and $3 \%$ of tank biomass. Tanks were cleaned daily.

Temperature, salinity, $\mathrm{pH}$ and oxygen were checked daily with WTW ${ }^{\mathrm{TM}}$ devices yielding values that were 10 to $24^{\circ} \mathrm{C}, 14$ to $16 \%$, very close to 7 , and 8 to $10 \mathrm{mg} \mathrm{l}^{-1}$, respectively. Winter vernalisation was obtained by opening the doors of the building. Ammonium (indophenol blue), nitrite and nitrate contents in the water were monitored monthly in the biological filter inlet and outlet with a Spectrophotometer (Spectronic 401, Milton Roy) and Merck quick colour kits, respectively. Outlet values of tanks were 0.007 to $0.16 \mathrm{mg} \mathrm{l}^{-1}$ (ammonium), 0.05 to $0.1 \mathrm{mg} \mathrm{l}^{-1}$ (nitrite), and 60 to $120 \mathrm{mg} \mathrm{l}^{-1}$ (nitrate).

Fish were evaluated on a 3 mo basis for weight, appearance and sexual maturation state by biopsy (from late 1999 onwards for Group 1 fish and from 2005 onwards for Groups 2 and 3) except those that looked too thin (i.e. in poor condition). Prior to these evaluations, fish were captured in a long sock-like net. In the $2 \mathrm{~m}$ deep tanks, a diver was necessary. Fish were then tranquillized by immersion for about $5 \mathrm{~min}$ in a bath containing clove oil (emulsified in ethanol; 1:10 clove oil:ethanol) added to water at a concentration of $40 \mathrm{ppm}$. Maturation stage was evaluated by sampling a piece of gonadal tissue via biopsy.

Selection of premature fish was performed in May (May 14 and 15, 2007 in the present study), corresponding to the peak period of wild brood fish captures in rivers, when fish swim upstream for potential spawning (Williot et al. 2002b).

Males with developed testes were selected and their gonadal texture was graded (Williot et al. 
2000b). For females, a pre-selection process involved evaluating the size, homogeneity, appearance, and degree of migration of germinal vesicle expressed by polarisation index (PI) of a sample of ovarian follicles (ovf) (Williot 2005). The lower the PI ( 15 ovarian follicles), the more advanced the maturation. One female, previously pre-selected, died $24 \mathrm{~h}$ post biopsy without any apparent cause. There were no internal injuries and the ovaries were fully developed. Pre-selected females belonged to Group $1(\mathrm{n}=1)$ and Group 2 ( $\mathrm{n}=$ 3 , those which entered the hatchery in 1995) (Table 1). Males were in Group $1(\mathrm{n}=1)$ and Group $2(\mathrm{n}=6)$ (Table 2). Fish were transferred on May 16 to 2 sepa- rate tanks $(4 \times 1 \mathrm{~m}, \varnothing \times h)$ supplied with flow-through freshwater.

The duration of the stay in freshwater extended beyond the 1 wk optimum duration previously determined (Williot et al. 2007) due to unforeseen circumstances (unavailability of experienced people). The final selection of ripe females occurred on June 12 and 13, for which the results are reported in Table 1 . The selection process for ripe females was based on a biotest that evaluated the in vitro maturation competence of ovf (Lutes et al. 1987). The in vitro maturation competence test was performed as follows: ovf ( $\mathrm{n}=33$ ) were placed one by one in the standard Siberian Stur-

Table 1. Acipenser sturio. Morpho-physiological characteristics of the pre-selected maturing females in 2007. In vitro maturation competence: maturation competence of ovarian follicles (ovf). GV: germinal vesicle; GVBD: germinal vesicle breakdown; PI: polarisation index; $\varnothing$ : mean diameter (mm). Blanks indicate no data

\begin{tabular}{|c|c|c|c|c|c|c|c|c|c|}
\hline $\begin{array}{l}\text { Code number } \\
\text { (birth year) }\end{array}$ & $\begin{array}{l}\text { Weight } \\
\text { (kg) }\end{array}$ & $\begin{array}{l}\text { Total length } \\
(\mathrm{cm})\end{array}$ & $\begin{array}{c}\text { Observations } \\
(\varnothing, \mathrm{mm})\end{array}$ & $\begin{array}{l}\text { Ovarian } \\
\text { follicles }\end{array}$ & $\begin{array}{c}\text { PI } \\
\text { Mean } \\
(\min -\max )\end{array}$ & - In vitro & $\begin{array}{l}\text { naturation co } \\
\text { Hormone } \\
(\%)\end{array}$ & $\begin{array}{c}\text { petence- } \\
\text { Control } \\
(\%)\end{array}$ & $\begin{array}{l}\text { Hormonal } \\
\text { injection }\end{array}$ \\
\hline 1 (1988) & 19.5 & 150 & $\begin{array}{c}\text { Abdomen not } \\
\text { swollen } \\
\text { Underdeveloped } \\
\text { ovaries } \\
\text { Ovf brittle }\end{array}$ & 2.3 & $\begin{array}{c}0.11 \\
(0.07-0.125)\end{array}$ & $\begin{array}{c}\text { GVBD } \\
\text { GV }\end{array}$ & 80 & 80 & Yes \\
\hline 2 (1994) & 27.4 & 172 & $\begin{array}{c}\text { Abdomen not } \\
\text { swollen } \\
\text { Underdeveloped } \\
\text { ovaries } \\
\text { Ovf very brittle }\end{array}$ & 2.3 & $\begin{array}{c}0.15 \\
(0.10-0.19)\end{array}$ & $\begin{array}{c}\text { GVBD } \\
\text { GV }\end{array}$ & Not tested & Not tested & No \\
\hline 3 (1994) & 8.5 & 117 & $\begin{array}{l}\text { Abdomen not } \\
\text { swollen } \\
\text { Developed ovaries }\end{array}$ & 2.5 & $\begin{array}{c}0.12 \\
(0.07-0.22)\end{array}$ & $\begin{array}{l}\text { GVBD } \\
\text { GV }\end{array}$ & 90 & 100 & Yes \\
\hline 4 (1994) & 19.2 & 151 & $\begin{array}{c}\text { Abdomen not } \\
\text { swollen } \\
\text { Underdeveloped } \\
\text { ovaries } \\
\text { Ovf brittle }\end{array}$ & 2.3 & $\begin{array}{c}0.13 \\
(0.07-0.19)\end{array}$ & $\begin{array}{c}\text { GVBD } \\
\text { GV } \\
\text { Damaged }\end{array}$ & $\begin{array}{l}100^{\mathrm{a}} \\
14^{\mathrm{c}}\end{array}$ & $\begin{array}{c}100^{b} \\
7^{c}\end{array}$ & Yes \\
\hline
\end{tabular}

Table 2. Acipenser sturio. Characteristics of spermiation in 2007. Time lapse for motility given in s and min. Blanks indicate no data

\begin{tabular}{|c|c|c|c|c|c|c|c|c|}
\hline \multirow{2}{*}{$\begin{array}{l}\text { Code number } \\
\text { (birth year) }\end{array}$} & \multirow{2}{*}{$\begin{array}{l}\text { Weight } \\
(\mathrm{kg})\end{array}$} & \multirow{2}{*}{$\begin{array}{c}\text { Total } \\
\text { length }(\mathrm{cm})\end{array}$} & \multirow{2}{*}{$\begin{array}{l}\text { Semen } \\
\text { vol. (ml) }\end{array}$} & \multirow[t]{2}{*}{ Aspect } & \multirow{2}{*}{$\begin{array}{c}\text { Initial } \\
\text { motility (\%) }\end{array}$} & \multicolumn{2}{|c|}{ Motility post water addition (\%) } & \multirow{2}{*}{$\begin{array}{c}\text { Held for } \\
\text { mating }\end{array}$} \\
\hline & & & & & & $30^{\prime \prime} \quad 1^{\prime}$ & $1^{\prime} 30^{\prime \prime}$ & \\
\hline $1(1994)$ & 14.4 & 138 & $\sim 40$ & Clear & \multicolumn{4}{|c|}{ Very rare spermatozoa } \\
\hline $2(1984 / 1985)$ & 24.3 & 176 & $\sim 180$ & Light milky & 0 & $50 \quad 20$ & 5 & Yes \\
\hline $3(1994)$ & 17.6 & 155 & $\sim 30$ & Light milky & 0 & 95 & 50 & Yes \\
\hline $4(1994)$ & 7.6 & 110 & 0 & & & & & No \\
\hline $5(1994)$ & 8.6 & 163 & 0 & & & & & \\
\hline $6(1994)$ & 13.1 & & Not injected & & & & & \\
\hline $7(1994$ & 8.8 & & $\begin{array}{l}\text { Died prior to } \\
\text { injection }\end{array}$ & & & & & \\
\hline
\end{tabular}


geon incubation media (SIS medium) to which progesterone was added $\left(1 \mathrm{\mu g} \mathrm{ml}^{-1}\right)$ (or not $=$ control) for $24 \mathrm{~h}$ at $18^{\circ} \mathrm{C}$ (Williot et al. 1991, Williot 1997). Each follicle was then evaluated for absence of germinal vesicle envelopes, i.e. germinal vesicle breakdown (GVBD), or presence of germinal vesicle (GV). When GVBD was at least 80 to $90 \%$, fish were considered as potentially reactive to hormonal stimulation.

Males and females were injected with mammalian GnRH at a rate of 5 and $10 \mu \mathrm{gg}^{-1}$. Injection was performed directly in the tank without handling the fish, or through the mesh of a sock-like net, allowing a gentle immobilisation of the fish. However, as fish were almost never in an optimal reproductive state (as judged by some of their morpho-physiological characteristics) a 2-injection procedure was applied; an initial priming dose (one-tenth of the dosage) followed by the remainder of the dose $12 \mathrm{~h}$ later (Williot et al. 2000a). On May 18, 2 males (6 and 7, Table 2) exhibited a sudden and dramatic mycosis. The skin became reddish and the mucus detached from the body. Male 7 died, whereas Male 6 was treated with malachite green ${ }^{1}$, survived and was not exposed to additional injections. Hormonal injections were given on May 19 at $\sim 22: 00 \mathrm{~h}$ and on May 20 at 10:00 h. Collection of ovulated eggs (stripping and further abdominal opening) and semen (polypropylene tube, Williot et al. 2000b), fertilisation (water-diluted semen), rinsing, removing stickiness (water suspension of clay), and care of brood fish were carried out as previously described for Siberian sturgeon (Williot et al. 1991, Williot et al. 2002b). Semen was selected mainly on a motility basis which took into account a visual estimation of the number of motile spermatozoa (\%), and their speed and type of movement on a 5 grade scale (rating 5 as the most active semen, Williot et al. 2000b). Semen was stored in covered beakers in the refrigerator $\left(\sim 8^{\circ} \mathrm{C}\right)$ until use.

Incubation was performed in McDonald jars as part of a closed thermo-regulated system at $18.5^{\circ} \mathrm{C}\left( \pm 0.2^{\circ} \mathrm{C}\right)$ equipped with UV treatment. As the quality of the gametes was not consistent, development of Saprolegnia sp. was prevented by applying a malachite green treatment ( 5 to $10 \mathrm{~g} \mathrm{~m}^{-3}$ for 20 to $30 \mathrm{~min}$, no water renewal during treatment). At the onset of hatching, jars were placed in a hatching trough $(2.5 \times 0.5 \times 0.3 \mathrm{~m})$ where the hatchlings were collected.

During incubation, embryogenesis success was monitored by sampling 90 to 180 embryos in order to limit potential defects from the monitoring process. This

\footnotetext{
1The use of malachite green is forbidden in France because it is potentially carcinogenic; however, as the fish in this study are not for human consumption and as malachite green is the most efficient substance available, we decided to use it to save the largest possible number of valuable specimens
}

approach was more risk averse than the recommended monitoring of 300 specimens for staging and survival assessments (Dettlaff et al. 1993).

A $Z$-test was used to compare embryonic survival of the 2 matings (SigmaStat ${ }^{\circledR} 3.1$ ), and significance was assessed at an alpha value of $5 \%$.

\section{RESULTS}

Four females exhibited signs of advanced sexual development, determined by sampling some large ovarian follicles. They belonged to Group 1 (Female 1) and Group 2 (Females 2, 3 and 4) (Table 1). With the exception of Female 3, it was possible to sample only very few ovf because cells were brittle. Ovf size was similar among individuals, with a slightly larger value in Female 3 ( 2.5 vs. $2.3 \mathrm{~mm}$ ). Advancement of germinal vesicle migration was not totally achieved, with mean PI values $\geq 0.11$. Minimum values were 0.07 in all females (except Female 2, with 0.10) and maximum values were close to 0.2 . Due to this highest PI value as well as the very brittle state of the ovf, the in vitro maturation competence test was not performed on the ovarian follicles of Female 2. Blackish yolk pigmentation was exhibited in 20 to $30 \%$ of ovf for Females 1, 3 and 4 .

The bio-test was easy to conduct on Females 1 and 3. However, in Female 4 a significant number of ovf were damaged, especially in the presence of the hormone (14 vs. 7 in the control) (Table 1). The follicular envelopes were broken so the oocyte shape was irregular and the germinal vesicle (or its absence in the case of GVBD) was not observable. In Female 1, $80 \%$ of GVBD was recorded in both batches, with and without hormone addition.

In spite of the dubious results for Females 1 and 4, Females 1, 3, and 4 were injected, as GVBD values were $\geq 80 \%$ in the presence of the hormone. Twentyfour $\mathrm{h}$ after the second injection, ovulation was recorded in Female 3, which already displayed some signs that it was 'over-mature.' Neither of the other 2 females presented signs of ovulation over a $6 \mathrm{~h}$ period after being handled and were later observed laying on the bottom of the tank.

Of the 5 injected males, 3 provided semen. However, semen of Male 1 contained very few spermatozoa and this semen was not retained. Judged by its motility, the semen of Male 3 (Group 2) was of better quality than that of Male 2 (the oldest animal Group 1) (Table 2).

Female 3 provided ovulated eggs that were divided into 3 batches according to their quality-related appearance in chronological order of collection. The first batch consisted of $95 \mathrm{~g}$ of probably 'poor quality' products (some ovulated eggs had broken down and 
Table 3. Acipenser sturio. Embryogenesis success of Female 3 at $18.5^{\circ} \mathrm{C}$. Stage name and number are as in Detlaff et al. (1993). Differences in survival rates were non-significant

\begin{tabular}{|c|c|c|}
\hline $\begin{array}{l}\text { Time post- } \\
\text { fertilisation (h) }\end{array}$ & $\begin{array}{c}\text { Stage } \\
\text { name (stage } \\
\text { number) }\end{array}$ & $\begin{array}{l}\text { Survival }(\%) \\
\text { o3 } \times 0^{7} 2 \\
\text { o } 3 \times 0^{7} 3\end{array}$ \\
\hline 4 & $\begin{array}{l}\text { 2nd cleavage, } \\
\text { initiation of 3rd } \\
\qquad(5-6)\end{array}$ & $\begin{array}{c}70 \\
80 \\
(Z=1.7 ; \mathrm{p}=0.09)\end{array}$ \\
\hline 24.30 & $\begin{array}{l}\text { Early and middle } \\
\text { gastrula } \\
(14-15)\end{array}$ & $\begin{array}{c}66 \\
71 \\
(Z=0.57 ; \mathrm{p}=0.57)\end{array}$ \\
\hline 73.50 & $\begin{array}{l}\text { Tail tip approaches } \\
\text { the heart (onset of } \\
\text { heart beat) (30) }\end{array}$ & $\begin{array}{c}47 \\
54 \\
(Z=0.92 ; \mathrm{p}=0.36)\end{array}$ \\
\hline 90.15 & $\begin{array}{l}\text { Onset of hatching } \\
\qquad(34-35)\end{array}$ & $\begin{array}{c}39 \\
38 \\
(Z=0.12 ; \mathrm{p}=0.9)\end{array}$ \\
\hline
\end{tabular}

there were ovarian plugs). The second batch consisted of $81 \mathrm{~g}$ of apparently 'better quality' eggs with few ovarian plugs, and the third consisted of $525 \mathrm{~g}$ of apparently 'high quality' ovulated eggs. There were 84 ovulated eggs per gram in the third batch. The first 2 batches were fertilised by semen from Male 3, which apparently had the best sperm quality, as judged by motility. The third batch was divided into 2 equal parts, each being fertilised by 1 of the 2 retained batches of semen. Embryogenesis success is reported for Batch 3, as the first 2 batches did not experience successful fertilisation (Table 3). Fertilisation rates assessed $4 \mathrm{~h}$ post fertilisation were fairly good (70 and $80 \%$ ), with no significant differences between the 2 batches. Embryonic survival declined at a similar rate for both batches up to the onset of hatching, which lasted for about $24 \mathrm{~h}$. Unusual localised developmental figures appearing as limited expansion of vitellus outside the yolk sac were observed in both batches during late embryogenesis (post neurula). A large proportion of embryos had difficulty in hatching and getting out of the McDonald jars. They did not exhibit positive photosensitivity, so sorting was difficult. However, 11000 larvae were obtained, 6800 from the Male 3 mating, and 4200 from the Male 2 mating. The first feeding occurred 10 to $11 \mathrm{~d}$ post-hatch at $\sim 18.4^{\circ} \mathrm{C}$ and was comprised of $1 \mathrm{~d}$ old Artemia salina nauplii.

\section{DISCUSSION}

At present, all successes in the entire sturgeon farming cycle have been obtained in freshwater across a range of species: Acipenser naccarii (Arlati et al 1988), A. transmontanus (Struffenegger 1992, Logan et al.
1995, Webb et al. 1999, 2001), A. stellatus, A. gueldenstaedtii, A. ruthenus and Huso huso (Chebanov \& Savelyeva 1999). The present study involved obtaining fertile gametes from fish continuously held in brackish water (14 to $16 \%$ ), apart from the 5 wk spent in freshwater to mimic upstream migration. Two females exhibited complete ovary development in our farming conditions, as did 1 male (Male 3). Female 3 and Male 3 belonged to Group 2, i.e. fish which were born in 1994 and entered the hatchery in 1995. Complete testis development had already been recorded in similar water salinity conditions (Williot et al. 2007). Results recorded in the Cemagref facility in 2008 reinforce the present findings, as 3 females of Group 2 ovulated under the same conditions and procedures (P. Gonthier pers. comm.). We do not know whether this brackish salinity level is necessary or only optional for gametogenesis in A. sturio. In this respect, further observation of the few fish held in freshwater in the Institute of Freshwater Ecology and Inland Fisheries of Berlin will be of the utmost importance (Kirschbaum et al. 2000).

The only fish which ovulated (Female 3) was the one for which the results of the bio-test were decisive, with $90 \%$ GVBD in the presence of the hormone and $0 \%$ GVBD in the control conditions. The wide range in germinal vesicle migration might be interpreted as a sign of underdevelopment. However, the first 2 batches of ovulated eggs were considered over-mature products. Similar observations were reported from the wild-originated female in 1995 (Williot et al. 2000a). This might be responsible for the continuous decline in embryogenesis, which was similar in both matings.

The premise of this captive breeding programme is that the bio-test method, and in particular the incubation media, are effective. The SIS incubation media based on Siberian sturgeon plasma characteristics has already been shown to provide the best results (sensitivity and absence of spontaneous maturation) compared with any other tested incubation media (L-15, Ringer[s] among others) (Williot 1997). Later, the method was successfully applied to other sturgeon species such as Acipenser sturio (Williot et al. 1997, 2000a) and A. ruthenus (Williot et al. 2005a).

The cause of partial ovary development of Females 1, 2 and 4 in the present study, and those already reported (Williot \& Rouault 2008) is still unknown. It has been postulated that high summer water temperatures could be responsible. As such, a thermo-regulated system was set up in September 2006, the effects of which will probably be seen in the next few years.

In spite of similar rates of development success among the embryos produced by the 2 matings, Male 3 produced many more hatchlings than Male 2. This suggests a potential relationship with semen motility, which was better in the case of the younger Male 3 
(13 yr old). Male 2, the older fish at 23 yr old and the sire of the 1995 cohort, last matured (i.e. last complete testis development) in 2002. However, this is highly speculative given the low sample size. Overall, the embryogenesis was more rapid in the present study than in 1995, as illustrated by the earlier onset of hatching compared with that already described $(90 \mathrm{~h}$ 15 min vs. $98 \mathrm{~h}$ ); this is due to a slightly higher water temperature (18.5 vs. $\left.17.5^{\circ} \mathrm{C}\right)$.

Overall, the poor quality of gametes strongly suggests that the holding duration in freshwater, $5 \mathrm{wk}$ in the present study, was too long as compared with the previously suggested optimum duration of $1 \mathrm{wk}$ (Williot et al. 2007). Additionally, food deprivation should probably start earlier than at the time of transfer to freshwater. We propose an alternative schedule: stop feeding, transfer to freshwater 4 to 6 wk (assessment of upstream duration from Magnin [1962]) later, and initiate reproduction attempts 1 wk later.

Hatchling behaviour was similar to that recorded in 1995; we did not observe a phototactic reaction. As a result, sorting was very difficult (Williot et al. 2000a). First feeding occurred sooner than in the 1995 attempt (10 to 11 vs. $16 \mathrm{~d}$ post-hatch) because of the slightly higher temperature $\left(18.4\right.$ vs. $\left.17.5^{\circ} \mathrm{C}\right)$ (Williot et al. 2005b).

Findings from this preliminary investigation suggest that further research is needed. Topics for future research should include: (1) attempt to spawn fish that are held continually in freshwater, (2) determine the best conditions for transfer of preselected fish from brackish water to freshwater, (3) describe the behaviour of hatchlings, and (4) study the fundamentals of osmoregulation. The collective goal of this research should be to enhance the effectiveness of the captive breeding programme, increase populations of wild Atlantic sturgeon, and to improve our understanding of the biological knowledge of this species.

Acknowledgements. The authors are grateful to Charlie Roqueplo and Mario Lepage for their help in capturing fish held in $2 \mathrm{~m}$ deep tanks, to 3 anonymous referees and to the editor for valuable comments that greatly improved the quality of the paper.

\section{LITERATURE CITED}

Arlati G, Bronzi P, Colombo L, Giovannini G (1988) Induced breeding of the Italian sturgeon (Acipenser naccarii) raised in captivity. Riv Ital Aquacol 23:94-96

Beamesderfer RCP, Farr RA (1997) Alternatives for the protection and restoration of sturgeons and their habitat. Environ Biol Fishes 48:407-417

Chebanov MS, Savelyeva EA (1999) New strategies for brood stock management of sturgeon in the Sea of Azov basin in response to changes in patterns of spawning migration. J Appl Ichthyol 15:183-190
Dettlaff TA, Ginsburg AS, Schmalhausen OI (1993) Sturgeon fishes. Developmental biology and aquaculture. SpringerVerlag, Berlin and Heidelberg

Holcik J, Kinzelbach R, Sokolov LI, Vassilev VP (1989) Acipenser sturio Linnaeus, 1758. In: Holcik J (ed) The freshwater fishes of Europe. Aula Verlag, Wiesbaden, p 367-394

Kirschbaum F, Gessner J, Williot P (2000) Restoration of Acipenser sturio L., 1758 in Germany: growth characteristics of juvenile fish reared under experimental indoor conditions. Bol Inst Esp Oceanogr 16:157-165

Logan SH, Johnston WE, Doroshov SI (1995) Economics of joint production of sturgeon (Acipenser transmontanus Richardson) and roe for caviar. Aquaculture 130:299-316

Ludwig A, Williot P, Kirschbaum F, Lieckfeld D (2004) Genetic variability of the Gironde population of Acipenser sturio. In: Gessner J, Ritterhoff J (eds) Species differentiation and population identification in the sturgeons Acipenser sturio L. and Acipenser oxyrhinchus. Bundesamt Naturschutz 101:54-72

Lutes PB, Doroshov SI, Chapman F, Harrah J, Fitzgerald R, Fitzpatrick M (1987) Morpho-physiological predictors of ovulatory success in white sturgeon, Acipenser transmontanus Richardson. Aquaculture 66:43-52

Magnin E (1962) Recherches sur la systématique et la biologie des Acipenséridés. Ann Stat Centr Hydrobiol Appl 9: $7-242$

Rochard E, Castelnaud G, Lepage M (1990) Sturgeon (Pisces: Acipenseridae); threats and prospects. J Fish Biol 37: 123-132

> Rochard E, Lepage M, Meauzé L (1997) Identification et caractérisation de l'aire de répartition marine de l'esturgeon européen Acipenser sturio à partir de déclarations de captures. Aquat Living Resour 10:101-109

Struffenegger P (1992) Sturgeon farming in California: a promising industry. Aquac Eur 17:6-9

Trouvery M, Williot P, Castelnaud G (1984) Biologie et écologie d'Acipenser sturio. Etude de la pêcherie. Etude 17, Série Esturgeon 1, Cemagref, Bordeaux

Webb MAH, Van Eenennaam JP, Doroshov SI, Moberg GP (1999) Preliminary observations on the effects of holding temperature on reproductive performance of female white sturgeon, Acipenser transmontanus Richardson. Aquaculture 176:315-329

Webb MAH, Van Eenennaam JP, Grant GW, LinaresCazenave J, Fitzpatrick MS, Schreck CB, Doroshov SI (2001) Effects of thermal regime on ovarian maturation and plasma sex steroids in framed white sturgeon, Acipenser transmontanus. Aquaculture 201:137-151

Williot P (1997) Effects of incubation media on maturation of isolated ovarian follicles of Siberian sturgeon (Acipenser baerii Brandt) induced by sturgeon gonadotropic preparation or $17 \alpha, 20 \beta$, dihydroxy progesterone. Comp Biochem Physiol 118(C):285-293

Williot P (coord) (2005) Croissance et maturité sexuelle chez les individus en élevage de l'esturgeon Acipenser sturio en grand danger de disparition. Etude Cemagref EPBx 100, Bordeaux

Williot P, Rouault T (2008) Basic management for spawning of the cultured sturgeon, Acipenser sturio L., 1758, a critically endangered species. Cybium 32(2):334-335

Williot P, Brun R, Rouault T, Rooryck O (1991) Management of female breeders of the Siberian sturgeon, Acipenser baeri Brandt: First results. In: Williot P (ed) ACIPENSER. Cemagref Publication, Antony, p 365-379

> Williot P, Rochard E, Castelnaud G, Rouault T, Brun R, Lepage M, Elie P (1997) Biological characteristics of European 
Atlantic sturgeon, Acipenser sturio, as the basis for a restoration program in France. Environ Biol Fish 48: 359-370

Williot P, Brun R, Pelard M, Mercier D (2000a) Unusual induced maturation and spawning in an incidentally caught pair of adults of the critically endangered European sturgeon Acipenser sturio L. J Appl Ichthyol 16 (6): 279-281

Williot P, Kopeika EF, Goncharov B (2000b) Influence of testis state, temperature and delay in semen collection on spermatozoa motility in the culture Siberian sturgeon (Acipenser baerii Brandt). Aquaculture 189:53-61

Williot P, Arlati G, Chebanov M, Gulyas T and others (2002a) Status and management of Eurasian sturgeon: an overview. Int Rev Hydrobiol 87:483-506

Williot P, Rouault T, Brun R, Pelard M, Mercier D (2002b) Sta-

Editorial responsibility: Steven Cooke,

Ottawa, Ontario, Canada tus of caught wild spawners and propagation of the endangered sturgeon Acipenser sturio in France: a synthesis. Int Rev Hydrobiol 87:515-524

Williot P, Brun R, Rouault T, Pelard M, Mercier D (2005a) Attempts at larval rearing of the endangered western European sturgeon, Acipenser sturio L. (ACIPENSERIDAE), in France. Cybium 29:381-387

Williot P, Brun R, Rouault T, Pelard M, Mercier D, Ludwig A (2005b) Artificial spawning in cultured sterlet sturgeon, Acipenser ruthenus L., with special emphasis on hermaphrodites. Aquaculture 246:263-273

Williot P, Rouault T, Pelard M, Mercier D and others (2007) Building a brood-stock of the critically endangered sturgeon Acipenser sturio L.: problems associated with the adaptation of wild-caught fish to hatchery conditions. Cybium 31:3-11

Submitted: July 20, 2008; Accepted: November 21, 2008 Proofs received from author(s): January 26, 2009 